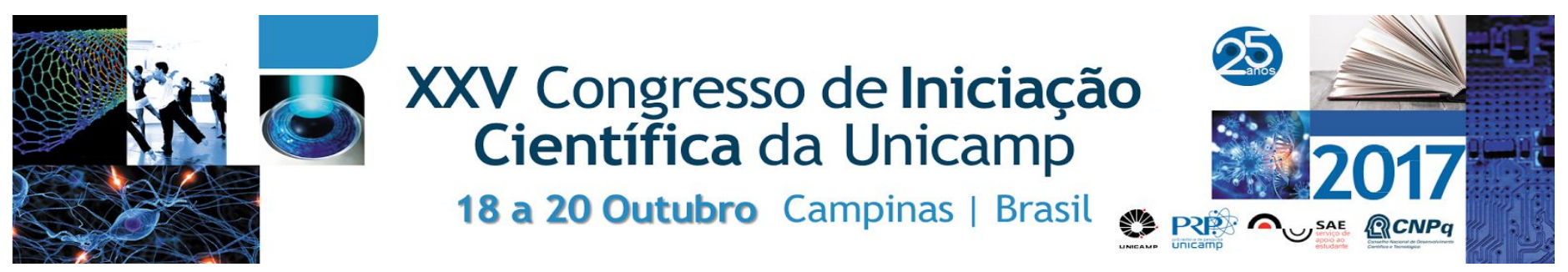

\title{
Livros de artista na era da tecnologia: pesquisas e experimentos práticos.
}

\author{
Lucas A. Scramim Perella*, Orientação: Profa. Dra. Luise Weiss
}

\section{Resumo}

Este projeto realizou investigações teóricas e experimentos práticos sobre o tema livros de artista, buscando uma relação com os aspectos tecnológicos, tanto como recursos de criação, quanto como técnica para o desenvolvimento dos livros.

Palavras-chave: Livros de artistas; arte e tecnologia; arte contemporânea

\section{Introdução}

Partindo do contexto da produção de livros de artista, o projeto teve um estudo teórico, e um estudo prático, com a criação de um livro de artista e um livro-objeto. Foi realizado um estudo breve sobre algumas das linguagens artísticas (literatura, cinema, fotografia, etc), com o propósito de criar um diálogo com os livros de artista, além da pesquisa da produção artística de alguns artistas, como Fernando Lindote e Paulo Bruscky. Dessa maneira, pude, junto da exploração prática, me aproximar da relação dos livros de artista e a sua possível relação com a tecnologia, chegando então na questão do itinerário de criação e na possibilidade de retrabalhá-lo por meio dos recursos tecnológicos.

\section{Resultados e discussões}

Dentro do processo de pesquisa, foi observado que pode haver uma inversão no itinerário de criação de uma obra, em que, partindo de um trabalho final, pode-se retroceder o processo, intervindo, e construindo um novo trabalho.

No livro de artista, busquei retrabalhar um material de caráter documental que fiz em Brasília-DF. Dessa forma, passei a explorar uma mescla entre fotomontagem e pintura digital, usando desenhos e imagens coletadas na cidade, retrabalhando-as, tendo como resultado um livro de artista.

Já no livro-objeto, usei a ideia do retroscópio para a sua construção física, e trabalhei a fragmentação de quadros de uma animação, imprimindo-os em papel, e colocados para que sejam reproduzidos, no retroscópio, como uma animação. Nesse caso, invertendo a forma de reprodução, em que um antigo equipamento usado no processo de criação, se torna a forma de reprodução em si.

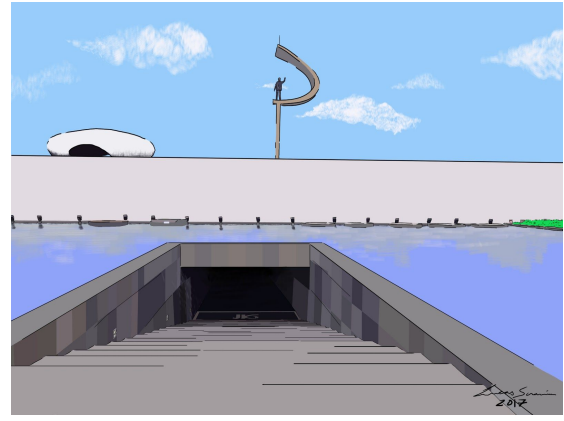

Imagem 2. Pintura digital, frente do Memorial JK, Brasília-DF, Brasil.

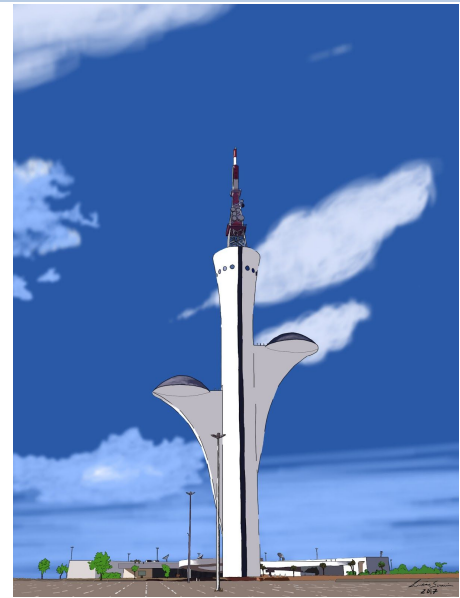

Imagem 1. Pintura digital, Torre de TV Digital, Brasília-DF, Brasil.

\section{Conclusões}

Foi possível concluir que a tecnologia se conecta à produção dos livros, tanto com a possibilidade do trabalho digital, com técnicas de fotomontagem, pintura, edição de fotos, quanto para a construção do livro-objeto, com o uso de aparatos tecnológicos ou de um processo que tenha como base o uso da tecnologia para a sua construção. Sendo também uma ferramenta para intervir em trabalhos prontos, como fotografias, obtendo um novo resultado com uma proposta diferente, retrabalhando o itinerário de criação.

\section{Agradecimentos}

Agradeço à Luise Weiss e Sylvia Furegatti pela ajuda, ao cnpq e a Unicamp.

CHARTIER, Roger. Do códex à tela: a trajetória do escrito. Estud. av [online]. 1994, vol.8, n.21, pp.185-199.

PLAZA, Julio. Arte, ciência, pesquisa: relações. Trilhas 6, $n^{\circ} 1$, Julho/dezembro, 1997: 21-32.

SILVEIRA, Paulo. A página violada: da ternura á injúria na construção do livro de artista. 2. ed. Porto Alegre, RS: Editora da UFRGS, 2008. 